\title{
Effects of iron stress on chromatic adaptation by natural phytoplankton communities in the Southern Ocean
}

\author{
M. A. van Leeuwe* ${ }^{*}$ K. R. Timmermans, H. J. Witte, G. W. Kraay, M. J. W. Veldhuis, \\ H. J. W. de Baar
}

Netherlands Institute for Sea Research, PO Box 59, 1790 AB Den Burg, Texel, The Netherlands

\begin{abstract}
Effects of iron stress on chromatic adaptation were studied in natural phytoplankton communities collected in the Pacific region of the Southern Ocean. Iron enrichment experiments (48 to $72 \mathrm{~h}$ ) were performed, incubating plankton comnunities under white, green and blue light respectively, with and without addition of $2 \mathrm{nM} \mathrm{Fe}$. Pigment ratios were affected by iron addition only to a minor extent. The pigment composition as dictated by the light conditions was similar for both the ironenriched and the unamended bottles. Upon iron addition, phytoplankton auto-fluorescence, as estimated by flow cytometry, decreased markedly, indicating iron stress of the endemic phytoplankton community. It was concluded that iron did not control chromatic adaptation via the pigment composition, but exerted a clear effect on the efficiency of electron transfer
\end{abstract}

KEY WORDS: Iron Chromatic adaptation Antarctic phytoplankton

\section{INTRODUCTION}

Phytoplankton in the open Pacific region of the Southern Ocean has to maintain growth under conditions of a dynamic light regime. Due to prevalent strong winds, the plant cells are frequently mixed through the water column, down to depths of more than $100 \mathrm{~m}$ (Mitchell \& Brody 1991). Light conditions thus change not only in intensity but also in spectral composition. With depth, light is increasingly attenuated towards shorter wavelengths, eventually leaving only blue light deep in the water column. Studies that address the photoadaptation response of phytoplankton towards light quantity and quality have a long history (e.g. Wallen \& Geen 1971, Richardson et al. 1983, Glover et al. 1987, Rivkin 1989, Aidar et al. 1994). Light quality affects photosynthesis. Relative to phytoplank-

\footnotetext{
- Present address: University of Groningen, Dept of Marine Biology, PO Box 14, 9750 AA Haren, The Netherlands. E-mail: m.a.van.leeuwe@biol.rug.nl
}

ton cells cultured under white and red light conditions, cells grown under blue light conditions show a more efficient functioning of the photosynthetic apparatus (Glover et al. 1987, Grotjohann et al. 1992). Chromatic adaptation does not necessarily involve adaptation of the pigment composition (Holdsworth 1985, Schofield et al. 1990). However, photosynthetic energy conversion and subsequent incorporation of carbon strongly depend on light quality. Cells grown under blue light may contain increased numbers of reaction centers per total chlorophyll (Voskresenskaya 1984). In its turn, the functioning of the reaction centers is also wavelength-dependent with respect to the quantum yield of photosynthesis (Kroon et al. 1993). Indirectly, blue light exerts its effects on photosynthesis via various enzyme systems, e.g. ribulose bisphosphate carboxylase, controlling the Calvin cycle (Ruyters 1984).

The photosynthetic apparatus requires iron to function. The quantum yield of photosynthesis is reduced under iron-limited conditions, resulting from a decrease in efficiency of electron transfer through the photosystems (Greene et al. 1991, 1992). In addition, 


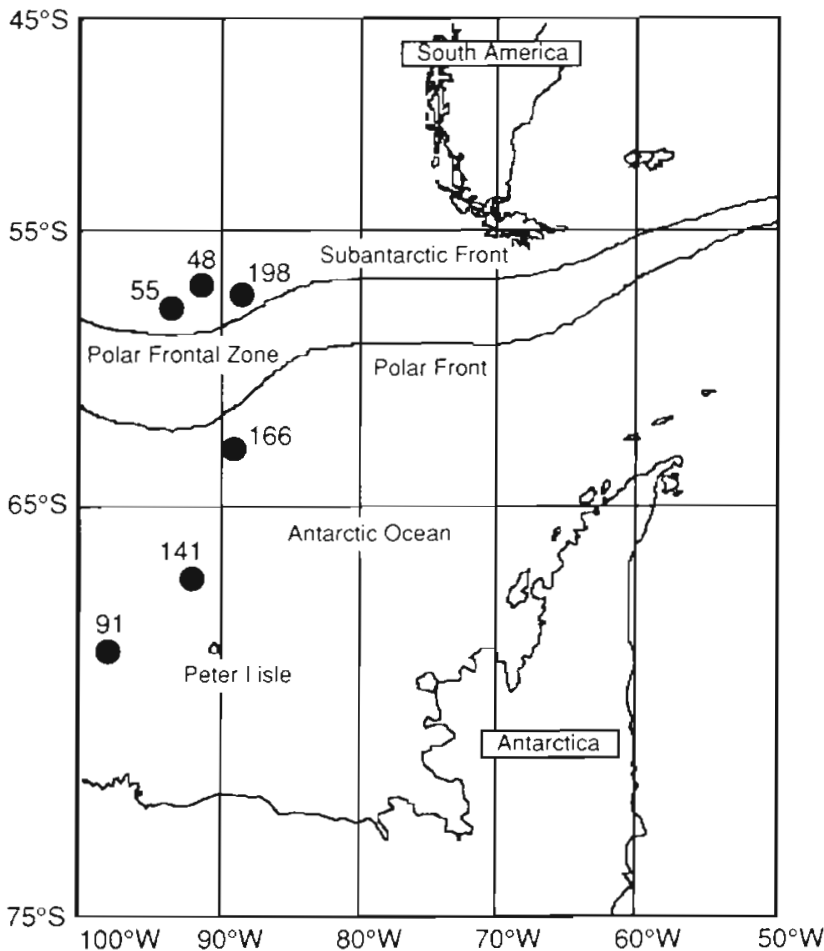

Fig. 1. Study area of cruise Ant XII/4 of the RV 'Polarstern' in April/May 1995 showing stations $(48,55,91,141,166$ and 198) where water was sampled for this study

iron stress may affect pigment synthesis (e.g. Geider et al. 1993, Pascal et al. 1995). Phytoplankton biomass in large parts of the Southern Ocean is often very low, whereas concentrations of major nutrients are high; at the same time, ambient iron concentrations are very low, <1 nM (Nolting et al. 1991, Westerlund \& Öhman 1991, de Baar et al. 1995). Because of this, it has been suggested that iron limits growth of the existing phytoplankton community (Martin et al. 1990). This hypothesis was first proposed and tested in the Subarctic Pacific by Martin \& Fitzwater (1988). In several incubation experiments in the Southern Ocean (de Baar et al. 1990, Buma et al. 1991, van Leeuwe et al. 1997) a response of the phytoplankton community upon the addition of iron was observed. Only since the application of sensitive fluorescence techniques that can measure in situ photosynthetic energy conversion (e.g. Kolber et al. 1994) has direct evidence for iron stress of endemic phytoplankton communities been provided.

Taking into account the dynamic light regime, which by itself imposes considerable stress upon the phytoplankton community (Sakshaug \& Holm-Hansen 1986, Mitchell \& Brody 1991), and the importance of iron in the process of photosynthesis, interaction of iron limitation with light limitation can be envisioned. During a cruise (Ant XII/4, RV 'Polarstern') in the Southern
Ocean (ca $90^{\circ} \mathrm{W}$ ) in April/May 1995, experiments were performed to study the role of iron in phytoplankton physiology. On board measurements confirmed that iron concentrations in the eastern section of the Southern Pacific Ocean were low (ca 0.2 to $0.3 \mathrm{nM}$ H. de Baar, J. de Jong, R. Nolting, M. van Leeuwe \& K. R. Timmermans unpubl.). To test whether the endemic phytoplankton community was adapted to the ambient spectral composition, natural plankton communities sampled at different locations were incubated under 1 of 3 different light spectra: white light, mimicking the entire light spectrum as encountered near the sea surface, and green and blue light, mimicking the light prevaling at the deeper layers of the euphotic zone. The aim of the experiments was to study the control of iron on pigment synthesis and photosynthetic efficiency, in relation to changes in the photosynthetic apparatus required for chromatic adaptation. Pigment composition and fluorescence of phytoplankton cells were analysed. The phytoplankton distribution pattern in the study area is described elsewhere (van Leeuwe et al 1998). Effects of iron stress on the nitrogen metabolism are described in an accompanying article by Timmermans et al. (1998, in this issue).

\section{METHODS}

Experimental procedures. During the ANT XII/4 cruise aboard the RV 'Polarstern', seawater for incubations was collected at 8 different stations, north and south of the Polar Front (Fig. 1). Dissolved iron concentrations in the seawater were low for all studies (Table 1: experimental series 48,55, 91, 141, 166 and 198). In order to prevent contamination with iron, all procedures were performed under ultraclean conditions using acid-cleaned Teflon or polycarbonate material. Seawater was collected using acid-cleaned GoFlo samplers fixed on a polyurethane coated titanium frame. Upon recovery of the frame, the Go-Flos were mounted to the outside wall of a specially designed, clean cool container. Tubes leading through the wall were connected to the Go-Flos, by which means it was possible to tap the seawater, leading it into 10 or 201 polycarbonate bottles (Nalgene) inside the container, without having to expose the seawater to the outside air. For each control bottle, an additional bottle was enriched with $2 \mathrm{nM} \mathrm{FeCl}_{3}$. The bottles were placed on rollers, and were rotated at 1 to $2 \mathrm{rpm}$ at ambient temperatures $\left(1\right.$ to $\left.5^{\circ} \mathrm{C}\right)$. For each experimental series, 3 sets of 2 bottles (i.e. a control and an iron-enriched bottle) were exposed to white, green or blue light respectively (PAR 70 to $80 \mu \mathrm{mol}$ photons $\mathrm{m}^{-2} \mathrm{~s}^{-1}$, light source: Philips TLD 36W/54), using Lee Flashlight filters for the blue and green treatments (Dark Green, HT 124, 
Table 1. Date, station, location, depth of collection $(\mathrm{m})$, water temperature $\left({ }^{\circ} \mathrm{C}\right)$ initial dissolved iron concentration (nM), dominant phytoplankton and light incubation and analyses carried out for samples collected in the Southern Ocean (April/May 1995). SAF: Subantarctic Polar Frontal zone; ACC: Antarctic Circumpolar Curent (after Read et al. 1995). (+) carried out; (-) not carried out

\begin{tabular}{|c|c|c|c|c|c|c|c|c|c|c|c|c|c|}
\hline Series & Date & Stn & $\begin{array}{l}\text { Latitude, } \\
\text { longitude }\end{array}$ & $\begin{array}{l}\text { Water } \\
\text { body }\end{array}$ & Depth & Temp & {$[\mathrm{Fe}]$} & $\begin{array}{l}\text { Dominant } \\
\text { phytoplankton }\end{array}$ & Blue & $\begin{array}{l}\text { Light } \\
\text { Green }\end{array}$ & White & $\begin{array}{l}\text { Ane } \\
\text { Fluor. }\end{array}$ & $\begin{array}{l}\text { alyses } \\
\text { Pigments }\end{array}$ \\
\hline 48 & $1 \mathrm{Apr}$ & 048 & $\begin{array}{l}57^{\circ} 15^{\prime} \mathrm{S} \\
91^{\circ} 14^{\prime} \mathrm{W}\end{array}$ & SA.F & 60 & 4 & 0.36 & $\begin{array}{l}\text { Flagellates, } \\
\text { small dinoflagellates }\end{array}$ & + & + & + & + & + \\
\hline 55 & $4 \mathrm{Apr}$ & 055 & $\begin{array}{l}57^{\circ} 53^{\prime} \mathrm{S} \\
93^{\circ} 32^{\prime} \mathrm{W}\end{array}$ & SAF & 40 & 4 & 0.43 & $\begin{array}{l}\text { Flagellates, } \\
\text { small dinoflagellates }\end{array}$ & + & + & + & + & + \\
\hline 91 & 9 Apr & 091 & $\begin{array}{l}68^{\circ} 31^{\prime} \mathrm{S} \\
97^{\circ} 10^{\prime} \mathrm{W}\end{array}$ & $\mathrm{ACC}$ & 60 & 1.5 & - & Diatoms & + & + & + & + & + \\
\hline 141 & $21 \mathrm{Apr}$ & 141 & $\begin{array}{l}67^{\circ} 13^{\prime} \mathrm{S} \\
91^{\circ} 50^{\prime} \mathrm{W}\end{array}$ & $\mathrm{ACC}$ & 40 & 1.5 & 0.53 & Diatoms & + & + & + & + & - \\
\hline 166 & $26 \mathrm{Apr}$ & 166 & $\begin{array}{l}62^{\circ} 60^{\prime} \mathrm{S} \\
89^{\circ} 30^{\prime} \mathrm{W}\end{array}$ & $\mathrm{ACC}$ & 35 & 1.5 & 0.33 & Flagellates & + & - & + & + & - \\
\hline 198 & 2 May & 198 & $\begin{array}{l}57^{\circ} 31^{\prime} \mathrm{S} \\
89^{\circ} 02^{\prime} \mathrm{W}\end{array}$ & SAF & 35 & 5 & 0.26 & $\begin{array}{l}\text { Flagellates, } \\
\text { small dinoflagellates }\end{array}$ & + & + & + & + & - \\
\hline
\end{tabular}



Fig. 2. Transmission spectra of the cool-white light source ( - white) and of the colours of the 2 Lee Flashlight filters used in the experiments (---- blue; --.- green)

and Lagoon Blue, $\mathrm{HT} \cdot 172$; Fig 2). The plankton was incubated under an $8 \mathrm{~h}$ light:16 h dark regime. At $t=0$, samples were taken for direct analysis of cell number and auto-fluorescence (applying flow cytometry), community structure (microscopy), and initial dissolved Fe concentrations. In order to follow the development of biomass, samples were taken for flow cytometry every $12 \mathrm{~h}$, until $t=72 \mathrm{~h}$, with intensified sampling from $t=$ $48 \mathrm{~h}$ onwards. At $t=48 \mathrm{~h}$, samples were taken for pigment analyses and cellular fluorescence. In addition, iron levels were followed throughout the experiments. The results on iron and nutrient analyses are described elsewhere (Timmermans et al. 1998).

Analytical procedures. Flow cytometry: Cells were collected every $12 \mathrm{~h}$. Cell numbers were determined by counting $1 \mathrm{ml}$ samples using a flow cytometer (Epics XL MCL, $488 \mathrm{~nm}$ laser, size range $<40 \mu \mathrm{m}$ ). Different clusters were distinguished on the basis of cell size

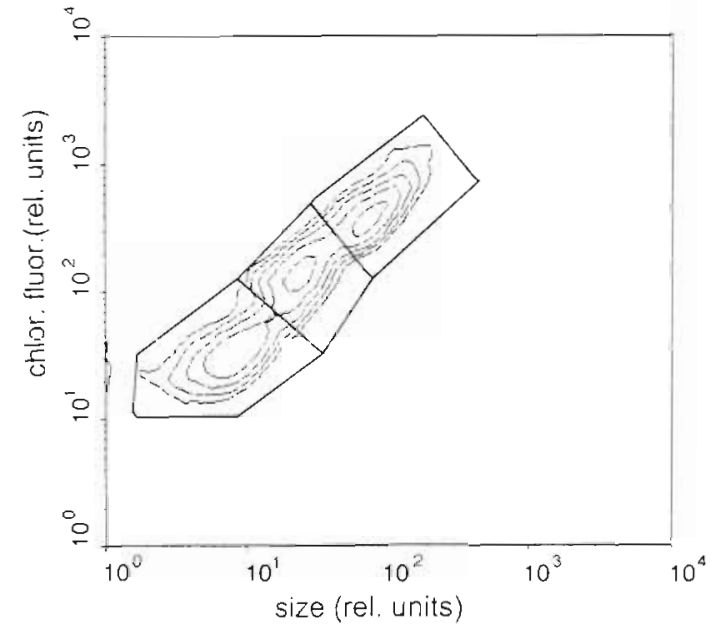

Fig. 3. Diagram of clusters as detected by the flow cytometer (Series 166, at $t=0$ ). The horizontal axis displays Forward Scatter (FS), as an indication of cell size, and the vertical axis displays autofluorescence (FL3: red fluorescence), indicating cellular chl a content. Values for FL3 were typically based on 1000 to 2000 observations, with a typical SD of 30 to $50 \%$

(Forward Scatter) and cellular fluorescence (Fig. 3). Red fluorescence (FL3) and orange fluorescence (FL2) were recorded using emission wavelengths between 656 and $700 \mathrm{~nm}$ and between 530 and $590 \mathrm{~nm}$ respectively. FL3 is a measure for chlorophyll a (chl a) fluorescence and FL2 a measure for phycoerythrin fluorescence. The flow rate and fluorescence signals were calibrated daily using fluorescence beads (EPICS). The cell samples were kept in the dark at least $20 \mathrm{~min}$ before analysis.

Pigments: Samples taken for pigment analyses (minimum 4 l) were filtered gently (pressure <0.15 bar) over GF/F Whatman filters. The filters were flash- 
cooled by dipping in liquid nitrogen and subsequently stored at $-20^{\circ} \mathrm{C}$ until analysis at the home laboratory. Pigments were extracted in $90 \%$ methanol $12 \%$ ammonium buffered). The pigment composition was determined by HPLC analysis according to Kraay et al. (1992) using a C18 column.

Community structure: The composition of the phytoplankton community was determined qualitatively by an inverted microscope after fixation with an acid Lugol's solution.

Not all parameters described were determined for all experimental series as large volumes of seawater were required for the different analyses.

\section{RESULTS}

\section{Community structure of the experiments}

Phytoplankton biomass was generally low, chl a lev-

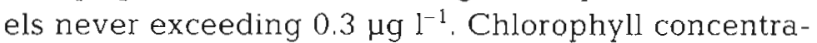
tions of the northernmost stations (north of the Subantarctic Front), covering Series 48, 55 and 198, averaged $0.28 \mu \mathrm{g} \mathrm{chl} \mathrm{a} \mathrm{l}^{-1}$. These chlorophyll levels coincided with total cell numbers averaging between 5000 and 7000 cells $\mathrm{ml}^{-1}$. Series 91, 141 and 166, with samples taken at stations in the Antarctic Circumpolar Current, contained cell numbers around 3000 cells $\mathrm{ml}^{-1}$, with lowest chl a values (ca $0.1 \mu \mathrm{g} \mathrm{l}^{-1}$ ) for Series 166. Series 91 and 141 had chl a levels of ca $0.3 \mu \mathrm{gl}^{-1}$, and were dominated by large diatoms (>25 $\mu \mathrm{m})$ ( 40 to

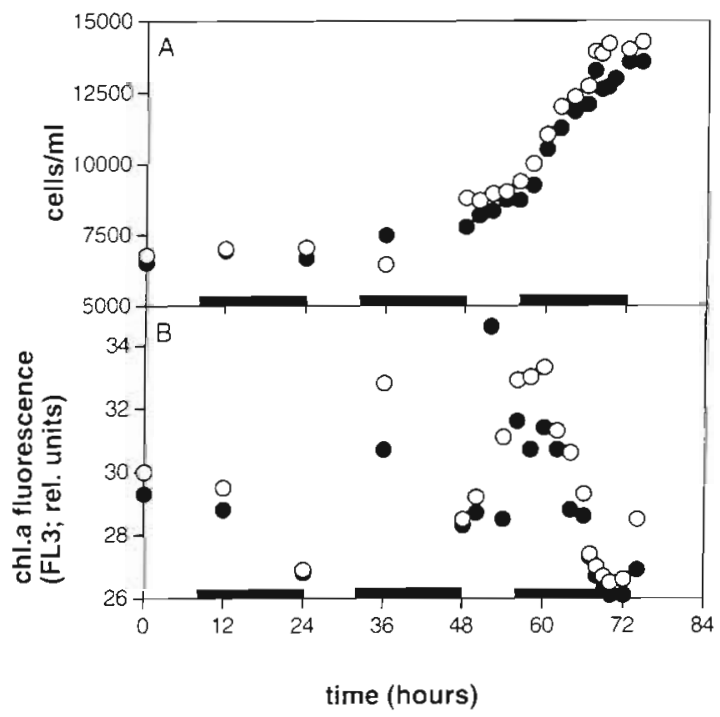

Fig. 4. Development of (A) cell numbers (cells $\mathrm{ml}^{-1}$ ) and (B) red fluorescence (arbitrary units) as recorded by flow cytometry for both a representative cluster from a control bottle (O) and an iron-enriched bottle (๑). Dark bars represent the dark periods
$60 \%$ of total chl a) which could not properly be quantified by the flow cytometer (Table 1). These stations contained high numbers of Fragilariopsis kerguelensis; several (unidentified) Coscinodiscus and Thalassiosira species were also observed. The diatom communities consisted furthermore of small pennates and various Chaetoceros species (Series 141). Various dinoflagellates were also present. The phytoplankton communities analysed for Series 48, 55 and 198 were composed mainly of small flagellates (ca $90 \%$ of chl a), typically Chrysophyceae (characterised by $19^{\prime}$ butanoyloxyfucoxanthin, BUTA) and Prymnesiophyceae (19'hexanoyloxyfucoxanthin, HEXA). In addition, elevated levels of chl $b$, indicating the presence of Prasinophyceae, were observed in Series 48 and 55 (ca 10\%) and 198 (ca $20 \%$ ) respectively. Series 166 was characterised by an enhanced ratio of fucoxanthin (FUCO) to HEXA, suggesting (in the absence of diatoms) the presence of Phaeocystis sp.

\section{Growth response}

For all experimental series a distinct lag phase in growth response was observed. Following a slight increase in cell number over the first $2 \mathrm{~d}$ of incubation, cell numbers did not increase again until after $48 \mathrm{~h}$ (Fig. 4A). Apparently, the structure of the phytoplankton community was no different at $t=0$ than at $t=48 \mathrm{~h}$. A clear diurnal signal was observed for chl a fluorescence (FL3, Fig. 4B). Growth patterns as depicted in Fig. 4 were identical for all experiments, irrespective of light quality. No significant differences between control bottles and iron-enriched bottles were observed.

\section{Pigments}

Experimental Series 48 and 55 consisted mainly of flagellates, and contained elevated levels of HEXA and BUTA. Part of the phytoplankton community was formed by green algae, as reflected in the presence of chl $b$ (Table 2, Fig. 5). Series 91 contained HEXA and FUCO, and elevated levels of chl $c_{2}$, which characterise a mixed population of diatoms and flagellates (Table 2).

None of the different plankton communities incubated showed a significant response towards iron addition in their relative pigment patterns (Fig. 5). Only a small, but significant, decrease in the chl $b$ concentration (expressed in percentage of the total pigment content) was observed following iron addition under white and blue light (ANOVA, p<0.05) (Fig. 5). This change was not consistent for green light incubations. An increase in the ratio of chl $c_{2}$ to $c_{3}$ for iron- 
Table 2. Chl $c$ and fucoxanthins expressed as percentages of total chl a. Values are presented for Series 48,55 and 91 for both the control bottles and the bottles enriched with iron ('2 nM Fe') under white, green and blue light conditions

\begin{tabular}{|c|c|c|c|c|c|c|c|c|c|}
\hline Light & Series & & Chl $c_{3}$ & $\mathrm{Chl} c_{2}$ & $\mathrm{Chl} c_{2+3}$ & Chl $c_{2}: \operatorname{chl} c_{3}$ & BUTA & HEXA & FUCO \\
\hline \multirow[t]{6}{*}{ White } & 48 & Control & 2.64 & 4.54 & 7.18 & 1.72 & 3.45 & 11.61 & 2.81 \\
\hline & & $2 \mathrm{nMFe}$ & 2.67 & 5.17 & 7.84 & 1.93 & 3.68 & 11.82 & 2.81 \\
\hline & 55 & Control & 2.63 & 3.96 & 6.59 & 1.51 & 3.24 & 11.81 & 2.85 \\
\hline & & 2 nM Fe & 2.42 & 4.38 & 6.80 & 1.81 & 3.66 & 12.62 & 3.14 \\
\hline & 91 & Control & 3.62 & 8.18 & 11.80 & 2.26 & 1.42 & 5.66 & 22.60 \\
\hline & & $2 \mathrm{nMFe}$ & 3.75 & 8.44 & 12.19 & 2.25 & 0.87 & 2.70 & 23.39 \\
\hline \multirow[t]{6}{*}{ Green } & 48 & Control & 4.07 & 6.24 & 10.31 & 1.53 & 5.40 & 13.25 & 6.28 \\
\hline & & $2 n M \mathrm{Fe}$ & 3.97 & 5.74 & 9.71 & 1.45 & 5.23 & 14.62 & 6.13 \\
\hline & 55 & Control & 3.64 & 5.17 & 8.81 & 1.42 & 4.90 & 11.68 & 6.77 \\
\hline & & $2 \mathrm{nM} \mathrm{Fe}$ & 4.76 & 5.40 & 10.16 & 1.13 & 3.75 & 13.81 & 5.95 \\
\hline & 91 & Control & 4.95 & 8.09 & 13.04 & 1.64 & 1.25 & 2.75 & 25.39 \\
\hline & & $2 \mathrm{nMFe}$ & 5.52 & 8.02 & 13.54 & 1.45 & 1.16 & 3.48 & 23.99 \\
\hline \multirow[t]{6}{*}{ GBlue } & 48 & Control & 3.62 & 5.98 & 9.60 & 1.65 & 5.28 & 10.85 & 3.30 \\
\hline & & $2 \mathrm{nM} \mathrm{Fe}$ & 3.89 & 6.40 & 10.29 & 1.64 & 5.28 & 12.63 & 3.84 \\
\hline & 55 & Control & 3.38 & 5.55 & 8.93 & 1.64 & 4.39 & 10.24 & 3.92 \\
\hline & & $2 \mathrm{nMFe}$ & 3.24 & 5.16 & 8.40 & 1.59 & 5.36 & 12.66 & 4.78 \\
\hline & 91 & Control & 4.26 & 8.18 & 12.44 & 1.92 & 1.00 & 4.47 & 22.30 \\
\hline & & $2 \mathrm{nMFe}$ & 4.40 & 7.87 & 12.27 & 1.79 & 1.13 & 4.66 & 22.73 \\
\hline
\end{tabular}

enriched bottles was observed under white light only (Table 2). No changes were observed within the pool of fucoxanthins in relation to iron addition (Table 2).

Iron addition resulted in a decrease in the ratio of chl $b$ to chl a (ANOVA, $p<0.05)$. For the total pool of chl $c\left(c_{1}, c_{2}, c_{3}\right\}$ as well as for the carotenoids, the ratio to chl a was not affected by the iron conditions. Neither the differences in pigment content nor the pigment ratios to chl a (as they were affected by light qualityl were found to be significant (Fig. 6).

\section{Cellular fluorescence}

For each experimental series different numbers of cell clusters with variable values for chl a fluorescence could be distinguished (FL3) (see Fig. 3). In addition to responses described for the phytoplankton community as a whole (i.e. considering the total community as one cluster), effects of iron stress were revealed by study of these clusters separately. Consistent with the decrease in cellular fluorescence observed for the total community upon iron addition, FL3 decreased for nearly all individual clusters. Under white light, a general decrease ranging from 2 to $20 \%$ was recorded (Fig. 7). Changes in FL3 recorded for green and blue light were highly variable, and did not show a clear trend (data not shown).

Orange fluorescence induced by phycoerythrin (FL 2) was detected for Series 48, 55 and 198 (Table 3). Values for FL2 were highest under green light. In response to iron addition, FL2 generally decreased (Fig. 7). Only under white light did FL2 not change for Series 198. The ratio of FL2 to FL3

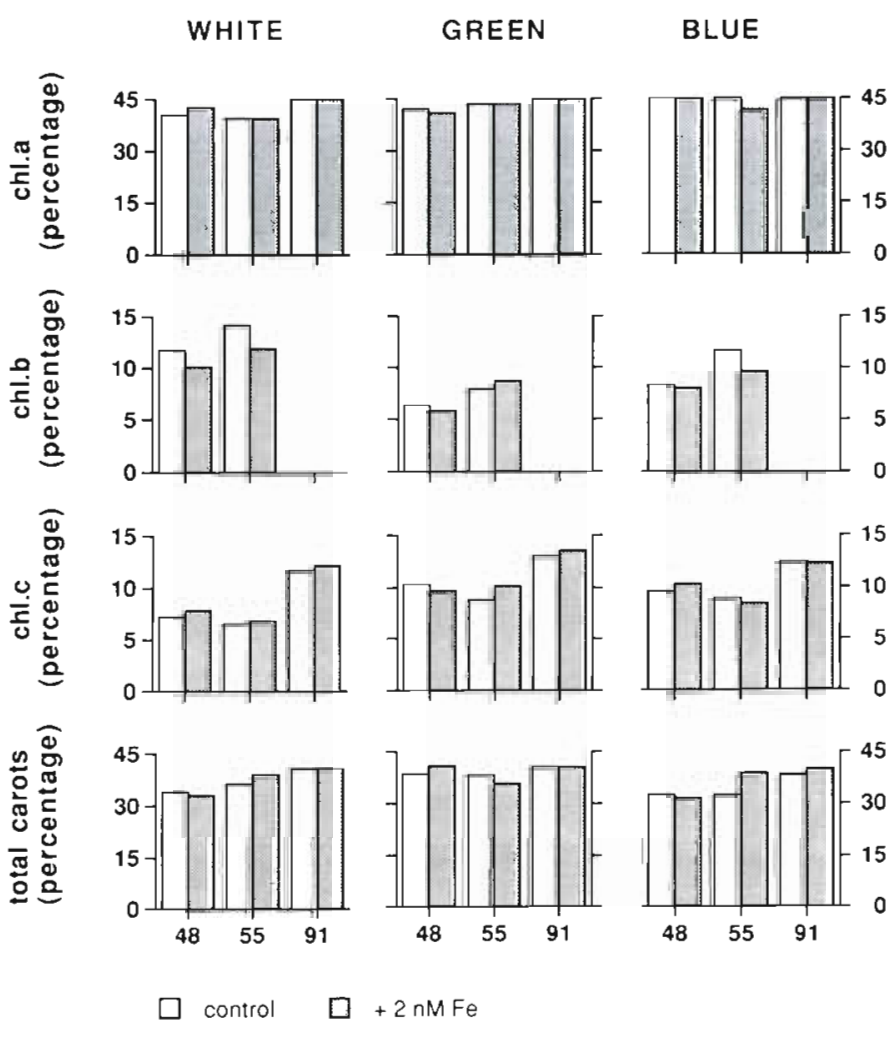

Fig. 5. Pigments expressed as a percentage of total pigments for phytoplankton cultured under white, green and blue light conditions with ( $2 \mathrm{nM} \mathrm{Fe}$ ) and without (control) iron addition. Pigments were measured in Series 48,55 and 91. Carots: carotenoids 
decreased for iron-enriched bottles relative to the control bottles under white and green light conditions (Table 3). Data recorded under blue light were again variable (data not shown).

\section{DISCUSSION}

\section{Development of the phytoplankton communities}

Open ocean areas are generally dominated by nanoplankton (3 to $10 \mathrm{~km}$; green algae, Prymnesiophyceae, Cryptophyceae). The pigment composition of these species is characterised by chl $b$ and/or chl $c_{2}$ and chl $c_{3}$. When mixed through the water column, and hence experiencing predominantly blue-green light. these species are considered to be best adapted by their pigment composition to the ambient light spectrum (Richardson et al. 1983, Bidigare et al. 1990). The phytoplankton communities encountered during the cruise confirmed this concept, although at 2 stations diatoms dominated. During incubation, the various phytoplankton communities behaved fairly similarly. A lag phase of $48 \mathrm{~h}$, as is generally observed during incubation experiments (e.g. Scharek et al. 1997), indicated that the observations described in this study largely concerned the cells of the initial plankton population, although a small increase in cell number was observed over the first $2 \mathrm{~d}$ (Fig. 4). Neither can we exclude the selective effect of grazers on the community structure. A general feature observed was the clear diurnal pattern in cellular fluorescence, with a maximum early in the dark period. A diurnal rhythm has previously been described, and may be ascribed to changes in the membrane configuration of the chloroplast (Prézelin \& Ley 1980). The magnitude of the fluorescence rhythm may form a serious bias if the fluorescence signal is directly correlated with phytoplankton biomass. This daily variation may also affect phytoplankton physiology. In order to avoid deviation due to cellular rhythm, samples from the incubations were taken at fixed hours.
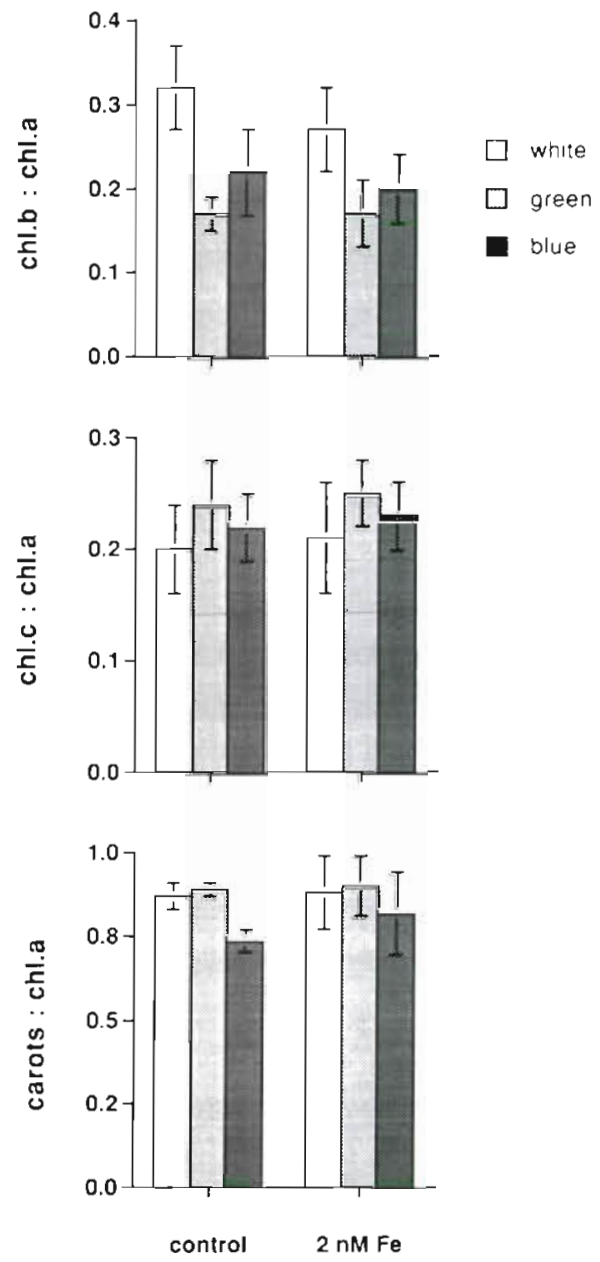

Fig. 6. Pigment to chl a ratios (avg $\pm S D, n=2$ or 3 ) for phytoplankton cultured under white, green and blue light conditions with ( $2 \mathrm{nM} \mathrm{Fe}$ ) and without (control) iron addition

\section{Pigments}

Iron is essential for pigment synthesis, as the synthesis of both chlorophyll (Guikema \& Sherman 1983, Greene et al. 1991) and carotenoids (Terry 1980, Geider et al. 1993, Morales et al. 1994, Pascal et al. 1995) requires iron. An increase in pigment content follow-

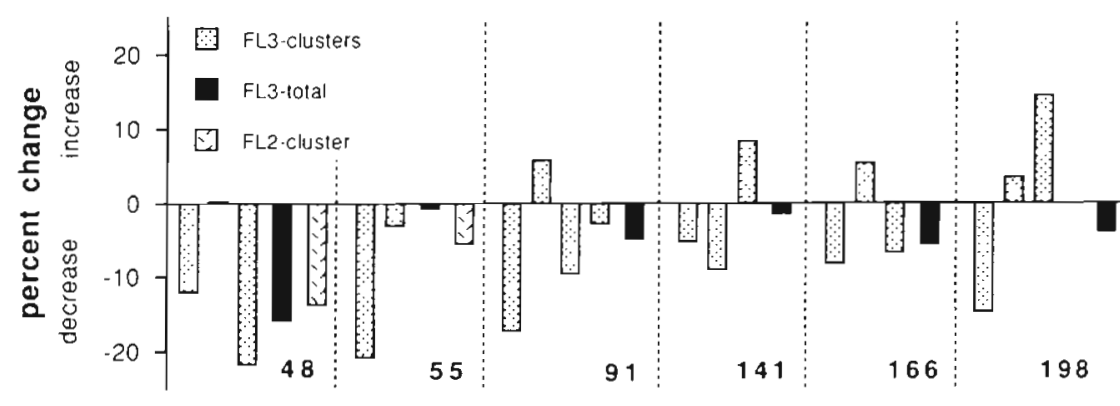

Fig. 7 Changes in cellular fluorescence upon iron addition (red $=$ FL3, orange $=$ FL2 , calculated as a percentage of fluorescence recorded for the control bottles [(iron-enriched-control)/controll $\times 100$. Fl2 always consisted of single clusters. FL3 is presented for separate clusters and for the community as a whole. Data are presented only for phytoplankton cultured under white light 
Table 3. Phycoerythrin fluorescence (FL2) and ratio of FL2 to FL3 (chlorophyll fluorescence) for phytoplankton communities exposed to white and green light

\begin{tabular}{|c|c|c|c|c|}
\hline \multicolumn{3}{|c|}{ Series } & \multirow{2}{*}{$\begin{array}{l}\text { White } \\
24.1\end{array}$} & \multirow{2}{*}{$\begin{array}{c}\text { Green } \\
27.9\end{array}$} \\
\hline FL2 & 48 & Control & & \\
\hline & & $2 \mathrm{nMFe}$ & 20.8 & 24.8 \\
\hline & 55 & Control & 23.6 & 25.1 \\
\hline & & $2 n M F e$ & 22.3 & 24.3 \\
\hline & 198 & Control & 28.6 & 35.9 \\
\hline & & $2 \mathrm{nMFe}$ & 28.6 & 35.2 \\
\hline \multirow[t]{6}{*}{ FL2:FL3 } & 48 & Control & 2.71 & 3.05 \\
\hline & & $2 \mathrm{nMFe}$ & 2.66 & 2.96 \\
\hline & 55 & Control & 3.29 & 3.39 \\
\hline & & $2 n M F e$ & 3.21 & 3.38 \\
\hline & 198 & Control & 3.76 & 3.74 \\
\hline & & $2 \mathrm{nMFe}$ & 3.66 & 3.72 \\
\hline
\end{tabular}

ing iron addition has generally been observed. Due to the short period of incubation applied in our experiments (all samples were taken at $t=48 \mathrm{~h}$ ) in. relation to low initial biomass, and the possible interfering effects of grazing, a response to iron addition in terms of absolute concentrations could not be determined accurately. The relative pigment composition examined for different plankton communities was, in general, similar for the control and the iron-enriched bottles. Iron stress apparently did not affect the response of pigment synthesis to light quality. This showed that the different pathways of pigment synthesis (Terry 1980 . Morales et al. 1990, Pascal et al. 1995) are in balance even under conditions of iron stress

Minor changes were only observed in the relative proportions of chlorophyll. Upon iron addition, the proportion of chl a decreased under white and blue light, relative to the accessory pigments. This resulted in a decrease in the chl $b$ to chl a ratio for phytoplankton incubated under white light. Possibly, the decrease in $c h l b$ was related to a shift in species composition. The differences in the pigment concentrations between the control and the iron-enriched bottles were only very small, and little growth may have been required to induce the observed changes. In fact, under white light the ratio of chl $c_{2}$ to chl $c_{3}$ increased for iron-enriched bottles (Table 2). Overall, the data indicate an increased contribution of diatoms for iron-enriched bottles under white light conditions. It appears that white light induced an enhanced growth response by diatoms relative to flagellates. This may be explained by the difference in pigment composition between the 2 groups. Diatoms contain elevated levels of fucoxanthin, which has an absorption maximum at $475 \mathrm{~nm}$ (e.g. Jeffrey 1980) and, upon iron addition, allows better use of available light, as compared to flagellates, which lack this carotenoid.

\section{Cellular fluorescence}

An important consequence of iron limitation is a decrease in efficiency of electron transfer due to a decrease in structural proteins associated with the PS II reaction centers (Greene et al. 1991, 1992, Geider et al. 1993). If the integrity of the photosynthetic membranes is restored as a result of iron addition, energy transfer within the photosystems may be enhanced. Direct indications of the recovery of the photosynthetic membranes can be acquired by examining cellular fluorescence. In response to iron addition, decreased cellular fluorescence was measured for the iron-enriched bottles relative to control bottles (Fig. 7). Since fluorescence signals were obtained by flow cytometry $\left(F_{c y t}\right)$, interpretation may not be straightforward. As thoroughly discussed by Neale et al. (1989), $F_{\text {cyt }}$ values are probably intermediate between minimal fluorescence $\left(F_{0}\right)$ and a maximum fluorescence signal $\left(F_{\max }\right)$, as is obtained after complete saturation of the primary electron acceptor $Q_{a}$ in PS II. $F_{\max }$ is most sensitive to the activity of PS II, and thus best records changes in efficiency of light transfer through the photosystems. The merits of fluorescence data obtained by flow cytometry are illustrated by Fig. 7. Trends observed for FL3 and FL2 (Appendix 1), indicating chl a and phycoerythrin fluorescence respectively, were reproducible, generally decreasing upon iron addition. This suggests that the fluorescence signal as recorded by flow cytometry was most sensitive to changes in the photochemistry of PS II. Upon iron addition, light is used more efficiently in the photosystems, and less light energy is spilled as fluorescence (Greene et al. 1992). Hence, the decrease in cellular fluorescence recorded for the phytoplankton population must be considered as a sign of iron stress of the original phytoplankton population.

These results are consistent with recent experiments performed in the eastern equatorial Pacific Ocean. Enrichment of natural phytoplankton with iron resulted in an immediate response in photosynthetic efficiency, leading to a reduction in variable fluorescence as recorded using a fast-repetition-rate fluorometer (Behrenfeld et al. 1996). An increase in the cellular concentrations of chlorophyll apparently followed at a slower pace. Cellular fluorescence measured after several days of incubating natural phytoplankton populations from the equatorial Pacific with and without iron addition reflected this increase in cellular pigment concentrations (Zettler et al. 1996). The fluorescence recorded by flow cytometry in this study showed an increase that could be attributed to increased cellular chl a concentrations.

Phycoerythrin-containing species were present in 3 of the 6 experimental series from stations sampled in Subantarctic waters. The FL2 signal was higher under 
green light than under white light. This illustrated adaptation towards green light; green light had its maximum at $510 \mathrm{~nm}$, which is near the absorption maximum of phycoerythrin (Vesk \& Jeffrey 1977. Glover et al. 1987). The ratio FL2:FL3 decreased for iron-enriched bottles (Table 3 ). These changes indicate a higher susceptibility of chl a relative to phycoerythrin towards iron deficiency (cf. Rueter \& Unsworth 1991 and Hardie et al. 1983). This may relate to the function of phycoerythrin in nitrogen storage (Boussiba \& Richmond 1980, Wyman et al. 1985), implying possible secondary effects of iron stress on phycoerythrin concentrations via the effects of iron on the nitrogen metabolism rather than direct effects on the pathways of phycoerythrin synthesis (Wilhelm 1995).

\section{Summary}

Phytoplankton communities in the Pacific region of the Southern Ocean responded to the addition of iron mainly through a decrease in cellular fluorescence, suggesting iron stress in the original phytoplankton. population. These experiments confirm the idea that within the process of photosynthesis, iron exerts its effect mainly on the efficiency of electron transfer, rather than on pigment synthesis. The changes in pig- ment ratio that did occur originated from changes in the phytoplankton community. Previous studies have already noted that the control on pigment synthesis is largely compensated for by a decrease in package effect, whereby the absorption cross section of phytoplankton cells increases under iron limitation (Greene et al. 1991). These processes are also of importance with regard to chromatic adaptation. It appears not so much that the constitution of the cellular pigment composition is responsible for the adaptation but that the quantum yield of photosynthesis is controlled by the efficiency of electron transfer. Thus, chromatic adaptation may be affected by iron stress predominantly in the functioning of the photosynthetic membranes, whereas pigment synthesis appears to be far less important.

Acknowledgements. The authors thank Dr Rainer Gersonde, the crew of the 'Polarstern' for support, and the Alfred. Wegener-Institut for allowing participation in ANT XII/4. We thank 3 anonymous reviewers and Jacqueline Stefels for critically reading the manuscript. Marla van Leeuwe was supported by grants from the Netherlands Organisation for Scientific Research (NWO) and the Commissie Antarctisch Onderzoek. This is NIOZ contribution no. 3274 . This research was partly supported by the project Marine Ecosystems Regulation: Trace Metal and Carbon Dioxide Limitations (MERLIM) of the European Union within the Marine Science and Technology Program under Contract No: MAS3-CT95-0005.

Appendix 1. Chlorophyll fluorescence (FL3) and phycoerythrin fluorescence (FL2), recorded at $t=48 \mathrm{~h}$. Effects of iron stress were found significant at $\mathrm{p}<0.02$ (ANOVA)

\begin{tabular}{|c|c|c|c|c|c|c|c|}
\hline \multirow[t]{2}{*}{ Series } & & \multicolumn{2}{|c|}{ White } & \multicolumn{2}{|c|}{ Green } & \multicolumn{2}{|c|}{ Blue } \\
\hline & & Control & $2 \mathrm{nMFe}$ & Control & $2 \mathrm{nMFe}$ & Control & $2 \mathrm{nM} \mathrm{Fe}$ \\
\hline \multirow[t]{4}{*}{48} & FL3 & 35.90 & 36.00 & 44.70 & 44.90 & 41.30 & 41.00 \\
\hline & FL3 & 10.00 & 7.83 & 9.93 & 9.50 & 9.17 & 9.13 \\
\hline & FL3 & 8.88 & 7.81 & 9.15 & 8.37 & 8.28 & 9.15 \\
\hline & FL2 & 24.10 & 20.80 & 27.90 & 24.80 & 23.90 & 26.80 \\
\hline \multirow[t]{3}{*}{55} & FL3 & 8.43 & 6.68 & 7.70 & 7.85 & 7.46 & 7.33 \\
\hline & FL3 & 7.17 & 6.95 & 7.40 & 7.19 & 7.17 & 7.38 \\
\hline & FL2 & 23.60 & 22.30 & 25.10 & 24.30 & 23.30 & 24.20 \\
\hline \multirow[t]{4}{*}{91} & FL3 & 62.40 & 51.70 & 59.60 & 58.30 & 56.80 & 47.20 \\
\hline & FL3 & 13.60 & 14.40 & 14.40 & 14.40 & 14.40 & 13.30 \\
\hline & FL3 & 221.50 & 200.30 & 247.00 & 243.30 & 193.40 & 129.50 \\
\hline & FL3 & 57.30 & 55.70 & 58.50 & 59.20 & 56.00 & 55.50 \\
\hline \multirow[t]{3}{*}{141} & FL3 & 13.50 & 12.80 & 13.30 & 14.50 & 13.00 & 14.80 \\
\hline & FL3 & 52.20 & 47.50 & 52.30 & 54.40 & 53.60 & 50.40 \\
\hline & FL3 & 228.70 & 247.90 & 260.60 & 272.60 & 258.50 & 235.50 \\
\hline \multirow[t]{3}{*}{166} & FL3 & 3.44 & 3.16 & & & 3.36 & 3.43 \\
\hline & FL3 & 14.60 & 15.40 & & & 14.70 & 15.60 \\
\hline & FL3 & 47.40 & 44.20 & & & 47.40 & 50.40 \\
\hline \multirow[t]{5}{*}{198} & FL3 & 4.03 & 3.44 & 5.16 & 4.91 & 4.56 & 4.37 \\
\hline & FL3 & 11.50 & 11.90 & 15.00 & 14.30 & 14.40 & 12.90 \\
\hline & FL3 & 37.40 & 42.80 & 44.90 & 44.80 & 62.20 & 44.40 \\
\hline & FL3 & 7.61 & 7.82 & 9.61 & 9.46 & 8.68 & 8.79 \\
\hline & FL2 & 28.60 & 28.60 & 35.90 & 35.20 & 32.60 & 32.90 \\
\hline
\end{tabular}




\section{LITERATURE CITED}

Aidar E, Gianesella-Galvāo SMF, Sigaud TCS, Asano CS, Liang TH and 8 others (1994) Effects of light quality on growth, biochemical composition and photosynthetic production in Cyclotella caspia Grunow and Tetraselmis gracilis (Kylin) Butcher. J Exp Mar Biol Ecol 180:175-187

Behrenfeld MJ, Bale AJ, Kolber ZS, Aiken J, Falkowski PG (1996) Confirmation of iron limitation of phytoplankton photosynthesis in the equatorial Pacific Ocean. Nature 383:508-511

Bidigare RR, Marra J, Dickey TD, Iturriaga R, Baker KS Smith RC, Pak H (1990) Evidence for phytoplankton succession and chromatic adaptation in the Sargasso Sea during spring 1985. Mar Ecol Prog Ser 60:113-122

Boussiba S, Richmond AE (1980) C-phycocyanin as a storage protein in the blue-green alga Sprirulina platensis. Arch Microbiol 125:143-147

Buma AGJ, de Baar HJW, Nolting RF, van Bennekom AJ (1991) Metal enrichment experiments in the Weddell-Scotia Seas: effects of iron and manganese on various plankton communities. Limnol Oceanogr 36:1865-1878

de Baar HJW, Buma AGJ, Nolting RF, Cadée GC, Jacques G Tréguer $P(1990)$ On ron limitation of the Southern Ocean experimental observations in the Weddell and Scotia Seas Mar Ecol Prog Ser 65:105-122

de Baar HJW, de Jong JTM, Bakker DCE, Loscher BM, Veth C, Bathmann U, Smetacek V (1995) Importance of iron for plankton blooms and carbon dioxide drawdown in the Southern Ocean. Nature 373:412-415

Geider RJ, LaRoche J. Greene RM, Olaizola M (1993) Response of the photosynthetic apparatus of Phaeodactylum tricornutum (Bacillariophyceae) to nitrate, phosphate, or iron starvation. J Phycol 29:755-766

Glover HE, Keller MD, Spinrad RW (1987) The effects of light quality and intensity on photosynthesis and growth of marine eukaryotic and prokaryotic phytoplankton clones J Exp Mar Biol Ecol 105:137-159

Greene RM, Geider RJ, Falkowski PG (1991) Effect of iron limitation on photosynthesis in a marine diatom. Limnol Oceanogr 36:1772-1782

Greene RM, Geider RJ, Kolber Z, Falkowski PG (1992) Ironinduced changes in light harvesting and photochemical energy conversion processes in eukaryotic marine algae. Plant Physiol 100:565-575

Grotjohann R, Rho MS, Kowallik W (1992) Influences of blue and red light on the photosynthetic apparatus of Chlorella kessleri. Bot Acta 105:168-173

Guikema JA, Sherman LA (1983) Organization and function of chlorophyll in membranes of cyanobacteria during iron starvation. Plant Physiol 73:250-256

Hardie LP, Balkwill DL, Stevens SE (1983) Effects of iron starvation on the physiology of the cyanobacterium Agmenellum quadruplicatum. Appl Environ Microbiol 45: 999-1006

Holdsworth ES (1985) Effect of growth factors and light quality on the growth, pigmentation and photosynthesis of two diatoms, Thalassiosira gravida and Phaeodactylum tricornutum. Mar Biol 86:253-262

Jeffrey SW (1980) Algal pigment systems. In: Falkowski PG (ed) Primary productivity in the sea. Plenum Press, New York, p 33-58

Kolber ZS, Barber RT, Coale KH, Fitzwater SE, Greene RM, Johnson KS, Lindley S, Falkowski PG (1994) Iron limitation of photosynthesis in the equatorial Pacific Ocean. Nature 371:145-149

Kraay GW, Zapata M, Veldhuis MJW (1992) Separation of chlorophylls $c_{1}, c_{2}$ and $c_{3}$ of marine phytoplankton by reversed-phase-C18-high-performance liquid chromatography. J Phycol 28:708-712

Kroon B, Prézelin BB, Schofield O (1993) Chromatic regulation of quantum yields for photosystem II charge separation, oxygen evolution, and carbon fixation in Heterocapsa pygmaea (Pyrrophyta). J Phycol 29:453-462

Martin JH, Fitzwater SE (1988) Iron deficiency limits phytoplankton growth in the north-east Pacific subarctic. Nature 331:341-343

Martin JH, Gordon RM. Fitzwater SE (1990) Iron in Antarctic waters. Nature 345:156-158

Mitchell BG, Brody EA (1991) Light limitation of phytoplankton biomass and macronutrient utilization in the Southern Ocean. Limnol Oceanogr 36:1662-1677

Morales F, Abadia A, Abadia J (1990) Characterization of the xanthophyll cycle and other photosynthetic pigment changes induced by iron deficiency in sugar beet (Beta vulgaris L.). Plant Physiol 94:607-613

Morales F, Abadia A, Belkhodja R, Abadia J (1994) Iron deficiency-induced changes in the photosynthetic pigment composition of field-grown pear (Pyrus communis L.) leaves. Plant Cell Environ 17:1153-1160

Neale PJ, Cullen JJ, Yentsch CM (1989) Bio-optical inferences from chlorophyll a fluorescence: What kind of fluorescence is measured in flow cytometry? Limnol Oceanogr $34: 1739-1748$

Nolting RF, de Baar HJW, van Bennekom AJ, Masson A (1991) Cadmium, copper and iron in the Scotia Sea, Weddell Sea and Weddell/Scotia Confluence (Antarctica). Mar Chem 35:219-243

Pascal N, Block MA, Pallett KE, Joyard J, Douce R (1995) Inhibition of carotenoid biosynthesis in sycamore cells deprived of iron. Plant Physiol Biochem 33.97-104

Prézelin BB, Ley AC (1980) Photosynthesis and chlorophyii a fluorescence rhythms of marine phytoplankton. Mar Biol 55:295-307

Read JF, Pollard RT, Morrison Al, Symon C (1995) On the southerly extent of the Antarctic Circumpolar Current in the southeast Pacific. Deep Sea Res II 42:933-954

Richardson K, Beardall J, Raven JA (1983) Adaptation of unicellular algae to irradiance: an analysis of strategies. New Phytol 93:157-191

Rivkin RB (1989) Influence of irradiance and spectral quality on the carbon metabolism of phytoplankton. I. Photosynthesis, chemical composition and growth. Mar Ecol Prog Ser 55:291-304

Rueter JG, Unsworth NL (1991) Response of marine Synechococcus (Cyanophyceae) cultures to iron nutrition. J Phycol 27:173-178

Ruyters G (1984) Effects of blue light on enzymes. In: Senger $\mathrm{H}$ (ed) Blue light effects in biological systems. SpringerVerlag, Berlin, p 283-301

Sakshaug E, Holm-Hansen O (1986) Photoadaptation in Antarctic phytoplankton: variations in growth rate, chemical composition and $P$ versus / curves. J Plankton Res 8:459-473

Scharek R, van Leeuwe MA, de Baar HJW (1997) Responses of Antarctic phytoplankton to the addition of trace metals. Deep Sea Res II 44:209-227

Schofield O, Bidigare RR, Prézelin BB (1990) Spectral photosynthesis, quantum yield and blue-green light enhancement of productivity rates in the diatom Chaetoceros gracile and the prymnesiophyte Emiliania huxleyi. Mar Ecol Prog Ser 64:175-186

Terry $N(1980)$ Limiting factors in photosynthesis. I. Use of iron stress to control photochemical capacity in vivo. Plant Physiol 65:114-120 
Timmermans KR, van Leeuwe MA, de Jong JTM, McKay R, Nolting RF, Witte $H$, van Ooyen J, Swagerman MJW, Kloosterhuis H, de Baar HJW (1998) Iron limitation in the Pacific region of the Southern Ocean: evidence from enrichment experiments. Mar Ecol Prog Ser 166:27-41

van Leeuwe MA, de Baar HJW, Veldhuis MJW (1998) Pigment distribution in the Pacific region of the Southern Ocean (autumn 1995). Polar Biol 19(5):348-353

van Leeuwe MA, Scharek R, de Baar HJW, de Jong JTM, Goeyens L (1997) Iron enrichment experiments in the Southern Ocean: physiological responses of plankton communities. Deep Sea Res II 44:189-207

Vesk M, Jeffrey SW (1977) Effect of blue-green light on photosynthetic pigments and chloroplast structure in unicellular marine algae from six classes. J Phycol 13:280-288

Voskresenskaya NP (1984) Control of the activity of photosynthetic apparatus in higher plants. In: Senger $H$ (ed)

Editorial responsibility: Otto Kinne (Editor)

Oldendorf/Luhe, Germany
Blue light effects in biological systems. Springer-Verlag, Berlin, p 407-418

Wallen DG, Geen GH (1971) Light quality and concentrations of protein, RNA, DNA and photosynthetic pigments in two species of marine plank:on algae. Mar Biol 10:44-51

Westerlund S, Ohman P (1991) Iron in the water column of the Weddell Sea. Mar Chem 35:199-217

Wilhelm SW (1995) Ecology of iron-limited cyanobacteria: a review of physiological responses and implications for aquatic systems. Aquat Microb Ecol 9:295-303

Wyman M, Gregory RPF, Carr NG (1985) Novel role for phycoerythrin in a marine cyanobacterium, Synechococcus strain DC2. Science 230.818-820

Zettler ER, Olson RJ, Binder BJ, Chisholm SW, Fitzwater SE, Gordon RM (1996) Iron-enrichment bottle experiments in the equatorial Pacific: responses of individual phytoplankton cells. Deep Sea Res II 43:1017-1029

Submitted: January 20, 1997; Accepted: March 12, 1998 Proofs received from author(s): May 15, 1998 